\title{
Windage Power Loss in Gas Foil Bearings and the Rotor-Stator Clearance of High Speed Generators Operating in High Pressure Environments
}

Robert J. Bruckner

Glenn Research Center, Cleveland, Ohio 


\section{NASA STI Program . . . in Profile}

Since its founding, NASA has been dedicated to the advancement of aeronautics and space science. The NASA Scientific and Technical Information (STI) program plays a key part in helping NASA maintain this important role.

The NASA STI Program operates under the auspices of the Agency Chief Information Officer. It collects, organizes, provides for archiving, and disseminates NASA's STI. The NASA STI program provides access to the NASA Aeronautics and Space Database and its public interface, the NASA Technical Reports Server, thus providing one of the largest collections of aeronautical and space science STI in the world. Results are published in both non-NASA channels and by NASA in the NASA STI Report Series, which includes the following report types:

- TECHNICAL PUBLICATION. Reports of completed research or a major significant phase of research that present the results of NASA programs and include extensive data or theoretical analysis. Includes compilations of significant scientific and technical data and information deemed to be of continuing reference value. NASA counterpart of peer-reviewed formal professional papers but has less stringent limitations on manuscript length and extent of graphic presentations.

- TECHNICAL MEMORANDUM. Scientific and technical findings that are preliminary or of specialized interest, e.g., quick release reports, working papers, and bibliographies that contain minimal annotation. Does not contain extensive analysis.

- CONTRACTOR REPORT. Scientific and technical findings by NASA-sponsored contractors and grantees.
- CONFERENCE PUBLICATION. Collected papers from scientific and technical conferences, symposia, seminars, or other meetings sponsored or cosponsored by NASA.

- SPECIAL PUBLICATION. Scientific, technical, or historical information from NASA programs, projects, and missions, often concerned with subjects having substantial public interest.

- TECHNICAL TRANSLATION. Englishlanguage translations of foreign scientific and technical material pertinent to NASA's mission.

Specialized services also include creating custom thesauri, building customized databases, organizing and publishing research results.

For more information about the NASA STI program, see the following:

- Access the NASA STI program home page at http://www.sti.nasa.gov

- E-mail your question via the Internet to help@ sti.nasa.gov

- Fax your question to the NASA STI Help Desk at $443-757-5803$

- Telephone the NASA STI Help Desk at 443-757-5802

- Write to: NASA Center for AeroSpace Information (CASI) 7115 Standard Drive Hanover, MD 21076-1320 
NASA/TM-2009-215826

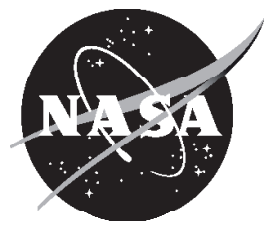

\section{Windage Power Loss in Gas Foil Bearings and the Rotor-Stator Clearance of High Speed Generators Operating in High Pressure Environments}

Robert J. Bruckner

Glenn Research Center, Cleveland, Ohio

Prepared for the

ASME Turbo Expo 2009

sponsored by ASME

Orlando, Florida, June 8-12, 2009

National Aeronautics and

Space Administration

Glenn Research Center

Cleveland, Ohio 44135 


\section{Acknowledgments}

The work presented in this paper was funded under the NASA Fundamental Aeronautics Program, Subsonic Rotary Wing Propulsion Project, Fission Surface Power Program, and the former Jupiter Icy Moons Orbiter Program.

This work was sponsored by the Fundamental Aeronautics Program at the NASA Glenn Research Center.

Level of Review: This material has been technically reviewed by technical management.

Available from

NASA Center for Aerospace Information 7115 Standard Drive

Hanover, MD 21076-1320
National Technical Information Service 5285 Port Royal Road Springfield, VA 22161

Available electronically at http://gltrs.grc.nasa.gov 


\title{
Windage Power Loss in Gas Foil Bearings and the Rotor-Stator Clearance of High Speed Generators Operating in High Pressure Environments
}

\author{
Robert J. Bruckner \\ National Aeronautics and Space Administration \\ Glenn Research Center \\ Cleveland, Ohio 44135
}

\begin{abstract}
Closed Brayton Cycle (CBC) and Closed Supercritical Cycle (CSC) engines are prime candidates to convert heat from a reactor into electric power for robotic space exploration and habitation. These engine concepts incorporate a permanent magnet starter/generator mounted on the engine shaft along with the requisite turbomachinery. Successful completion of the long-duration missions currently anticipated for these engines will require designs that adequately address all losses within the machine. The preliminary thermal management concept for these engine types is to use the cycle working fluid to provide the required cooling. In addition to providing cooling, the working fluid will also serve as the bearing lubricant. Additional requirements, due to the unique application of these microturbines, are zero contamination of the working fluid and entirely maintenance-free operation for many years. Losses in the gas foil bearings and within the rotor-stator gap of the generator become increasingly important as both rotational speed and mean operating pressure are increased. This paper presents the results of an experimental study, which obtained direct torque measurements on gas foil bearings and generator rotor-stator gaps. Test conditions for these measurements included rotational speeds up to 42,000 revolutions per minute, pressures up to 45 atmospheres, and test gases of nitrogen, helium, and carbon dioxide. These conditions provided a maximum test Taylor number of nearly one million. The results show an exponential rise in power loss as mean operating density is increased for both the gas foil bearing and generator windage. These typical "secondary" losses can become larger than the total system output power if conventional design paradigms are followed. A nondimensional analysis is presented to extend the experimental results into the CSC range for the generator windage.
\end{abstract}

\section{Introduction}

\section{High Pressure Power Cycles}

Power generation at remote locations such as the Moon, Mars, or onboard deep space satellites is paramount for robotic space exploration, in situ scientific investigation, and potential human habitation. In order to accommodate future missions, power requirements have risen into the 100's of kilowatts range. Closed Brayton Cycles (CBC) and Closed Supercritical Cycles (CSC) begin to look attractive to mission planners at these power levels (Ref. 1). In addition to these elevated power levels, the machinery that drives these power cycles will be required to operate without maintenance for several years. Thermo-nuclear heat sources will be required at such remote locations. Figure 1 shows a thermodynamic diagram of a high pressure gas cooled CBC. The figure also includes common cycles such as an Open Brayton Cycle and high pressure ratio turbofan engine. Figure 1 clearly demonstrates the unique feature that these high pressure cycles operate entirely above the pressure level of any current power cycle. Figure 2 shows a schematic of the components of such power cycles as well as an artistic conception of NASA's previously envisioned Jupiter Icy Moon Orbiter. Past studies of thermo-nuclear power cycles used multiple working fluids that were optimized for a specific purpose. Liquid metals are used for their high heat capacities as heat transfer fluids in the reactor, gases are used in the turbines to drive the generator shaft, and liquid coolants are used to reject heat through the radiators. Although each working fluid is optimized for a specific purpose, the system as a whole is prone to reliability and maintenance limitations. A single fluid cycle is potentially simpler and more reliable. To maintain high efficiencies gases must be used in the turbines. However, high pressure must be utilized in a single fluid cycle to enhance heat capacity and reduce in fluid machinery size. Supercritical cycles offer the additional advantages of enabling the use of a pump instead of a compressor, increasing the total power output of a given system volume, and increasing cycle efficiency at lower peak cycle temperatures. The challenge involved in the design of a single fluid system is that the working fluid must also serve as the coolant in the rotor-stator gap of the generator and as the lubricant in the bearings that support the turbomachinery (Ref. 2). A sample of potential architectures of the machinery that would be required to make the thermodynamic cycles a reality are shown in Figure 3. These designs indicate that all 4 state points are potential bearing locations. As such the performance of the high pressure gas bearings must be understood across the full range of cycle pressures and temperatures. There are no validated analytic methods available for gas bearings, which can span this property range. There are also no verified Taylor-Couette correlations for the high speeds and densities at which these machines will operate. Therefore an experimental approach is taken in this work. The working fluid, which flows through the rotor-stator 


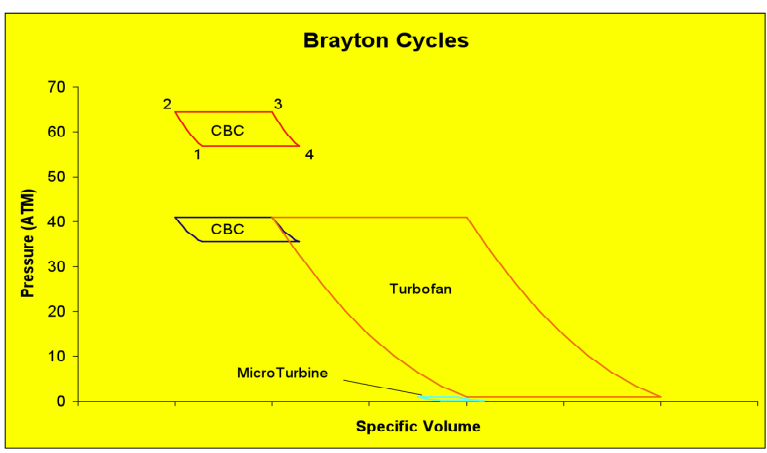

Figure 1.-Thermodynamic diagram of $\mathrm{CBC}$ and CSC cycle.

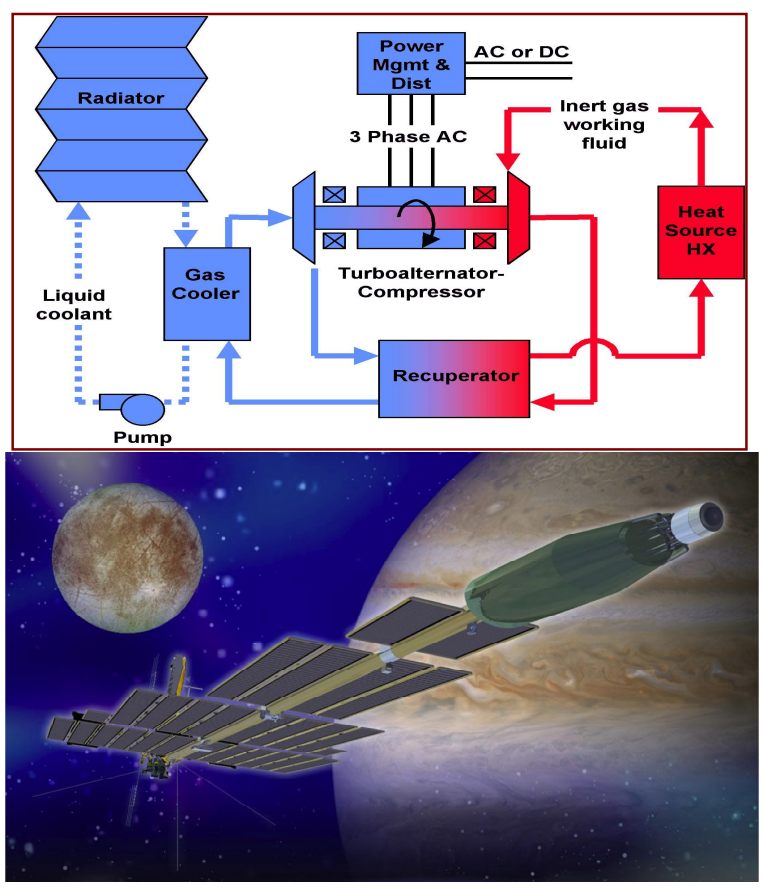

Figure 2.-(a) Schematic representation of $\mathrm{CBC}$ and CSC cycle. (b) Artists concept of the JIMO.

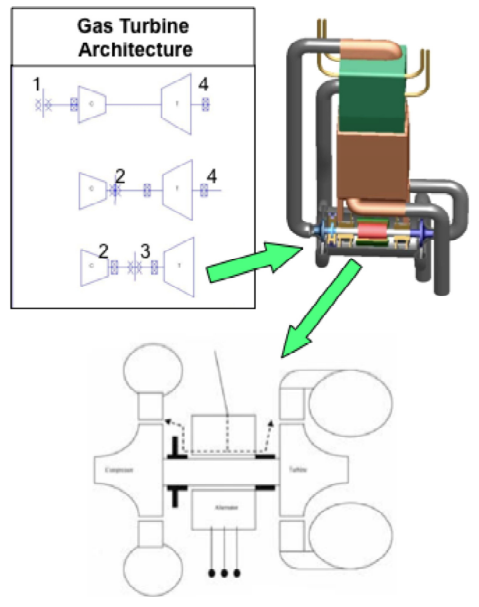

Figure 3.-Proposed CBC and CSC architectures and potential bearing and rotor-stator gap conditions. gap is limited to state point 1 or 2 due to the temperature limitations of electric machines. However, the kinematic viscosity, which is the key property governing the power loss in this part of the machine, can vary by 3 orders of magnitude. Again, no validated analytic method or correlations are available in this region, which is the motivation for the experimental approach taken in herein.

\section{Nomenclature}

$C_{m}$ Moment coefficient, nondimensional

$D$ Diameter of journal, mm (in.)

$D$ Load capacity coefficient, $\mathrm{mN} /\left(\mathrm{mm}^{3} \mathrm{krpm}\right)\left(\mathrm{lbf} /\left(\mathrm{in}^{3}{ }^{3}\right.\right.$ krpm))

$d \quad$ Rotor-Stator gap, m (in.)

$L \quad$ Length of bearing, $\mathrm{mm}$ (in.)

$M_{i}$ Moment due to windage on rotor, $\mathrm{N} \mathrm{m} \mathrm{(lbf} \mathrm{ft)}$

$N \quad$ Rotational speed, kilo-revolutions per minute (krpm)

$P \quad$ Ambient pressure of bearing cavity, atm

$R_{i} \quad$ Radius of rotor, $\mathrm{m}$ (in.)

$T$ Ambient temperature of bearing cavity, ${ }^{\circ} \mathrm{C}$

$T_{a}$ Taylor Number, nondimensional

$U_{i}$ Surface velocity of rotor, $\mathrm{m} / \mathrm{s}(\mathrm{ft} / \mathrm{s})$

$W$ Load supported by foil bearing, $\mathrm{N}$ (lbf)

$v$ Kinematic viscosity $\mathrm{m}^{2} / \mathrm{s}\left(\mathrm{ft}^{2} / \mathrm{s}\right)$

$\mu \quad$ Absolute viscosity Pa s (psi s)

$\rho$ Density $\mathrm{kg} / \mathrm{m}^{3}\left(\mathrm{lbm} / \mathrm{ft}^{3}\right)$

\section{Subscripts}

pl Preload

$t$ Total

$d w$ Deadweight

\section{Gas Foil Bearings}

Blok and VanRussom (Ref. 3) initially discovered the gas foil bearing in 1953. Since this discovery gas foil bearing supported turbomachines have been developed for a variety of applications over the past four decades (Ref. 4). Early applications were characterized by ambient pressure, low temperature, and lightly loaded conditions in centrifuges, cryogenic pumps, and aircraft air cycle machines. Recent advances in foil bearing load capacity and high temperature solid lubricant coatings have broadened the scope of potential applications. Microturbines for distributed power generation are commercially available products as are industrial oil-free compressors and blowers. Expendable oil-free turbojet engines and turbochargers have been demonstrated, while development programs are underway to convert larger aircraft engines to foil bearing supported systems (Refs. 5 to 7). Future applications that are under consideration which are in the systems analysis and preliminary design phase include microturbines for closed Brayton cycle power generation systems. 


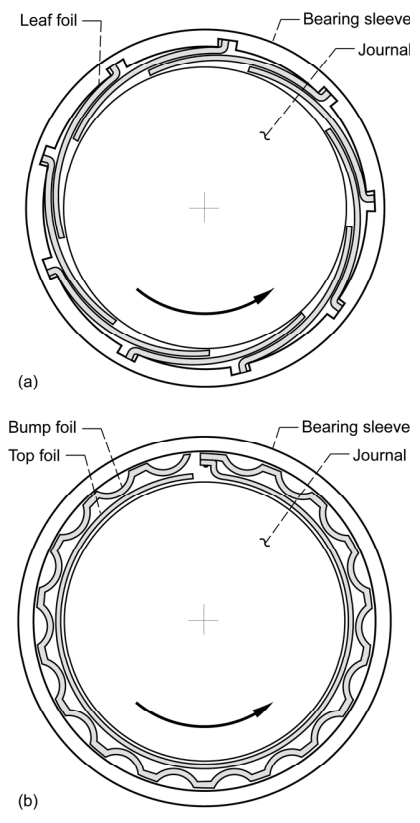

Figure 4.-Early foil bearing designs. (a) Leaf-type foil bearing.

(b) Bump-type foil bearing.

Foil gas bearings are compliant surface, self-acting hydrodynamic bearings that use ambient gas as the working fluid or lubricant. They do not require external pressurization and are typically constructed from several layers of sheet metal foils from which they derive their name. Figure 4 shows examples of early style journal bearings. The top bearing (Fig. 4(a)) is commonly referred to as an overlapping leaf design while the lower bearing (Fig. 4(b)) is a bump foil design. These names stem from the design of the compliant layer beneath the top foil. This innermost foil, top foil, serves as the hydrodynamic surface that traps the high pressure gas film between it and the rotating shaft. Foil gas bearings provide a means to eliminate the oil system, which can lead to lower system weight, and enhanced temperature capability. Additionally, the elimination of the oil system can lead to a maintenance-free machine. Under static conditions the top foil is preloaded against the shaft, $W_{p l}$, such that there is no static clearance or eccentricity between the stationary and rotating parts. This is a fundamental difference between the foil bearing and rigid hydrodynamic bearings and gives rise to additional parameters required to characterize these bearings. The static preload and dry sliding friction coefficient become important parameters in foil bearing characterization. Additionally, the design generation or load capacity coefficient is a third parameter that characterizes a foil journal bearing. Dellacorte (Ref. 8) identifies a design classification scheme that correlates compliant foundation complexity with bearing load capacity. A generation I design consists of a uniform stiffness foundation and is typical of early foil bearings. Generation II bearings vary the compliant foundation in one direction, for example in the axial or circumferential direction. Generation III bearings vary the

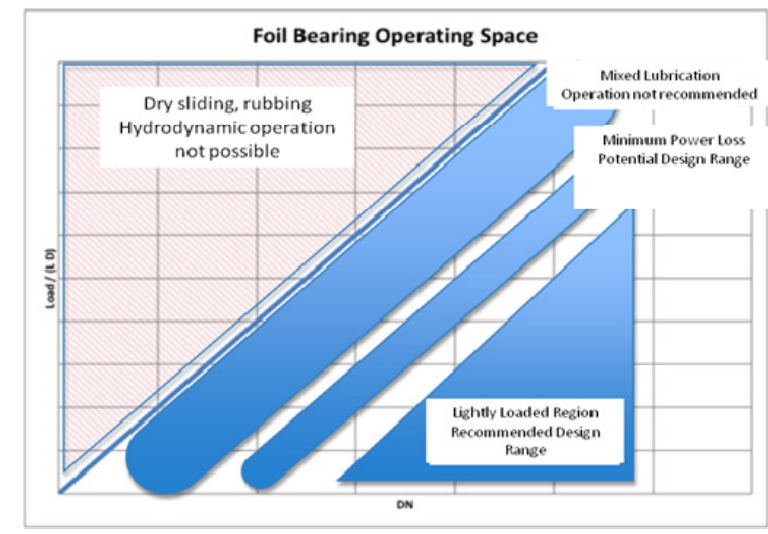

Figure 5.-General operating space of a gas foil bearing.

compliant foundation in at least two directions. DellaCorte goes on to quantify the load capacity of foil journal bearings according to Equation (1). In the steady state performance testing of foil bearings great care is taken to minimize all applied loads other than the preload and deadweight load such that the total load is known very accurately. The performance coefficient is typically $0.08,0.19$, and $0.27 \mathrm{mN} /\left(\mathrm{mm}^{3} \mathrm{krpm}\right)$ $\left(0.3,0.7\right.$, and $1.0 \mathrm{lbf} /\left(\right.$ in. $\left.\left.^{3} \mathrm{krpm}\right)\right)$ for generation I, II, and III bearings, respectively.

$$
\begin{aligned}
& W_{t}=\mathcal{D}(L \times D)(D \times N) \\
& \text { Where, } \\
& W_{t}=W_{p l}+W_{d w}+W_{\text {dynamic }}+W_{\text {thermal }}+
\end{aligned}
$$

For the foil bearings used in this test program, typical values for friction coefficient, preload and load capacity coefficient measured at room temperature and ambient pressure are $0.28, \quad 3.7 \quad \mathrm{kPa} \quad(0.54 \quad \mathrm{psi})$, and $0.27 \mathrm{mN} /\left(\mathrm{mm}^{3} \mathrm{krpm}\right)\left(1.0 \mathrm{lbf} /\left(\right.\right.$ in. $\left.\left.^{3} \mathrm{krpm}\right)\right)$. The friction coefficient is quite high, especially considering that low friction is desirable for this application. This high value is caused because only materials suitable for high temperature applications are used. The foil bearings use uncoated Inconel top foils and the shaft is coated with PS304, a high temperature solid lubricant (Refs. 9 to 11). Lower friction coefficients may be obtained for low temperature applications by using highly polished shaft surfaces with thin dense chrome plating and organic polymer coated topfoils.

Gas foil bearings exhibit a unique operating space based on their characteristics. Figure 5 presents the general operating space of a gas foil bearing in terms of rotational speed $(D N)$ and specific load. This plane is initially subdivided by the load capacity coefficient, which is a ray originating from the origin of the graph. The region above and to the left of this ray represents operation of a bearing beyond its load capacity in a mode of dry sliding and rubbing. Hydrodynamic operation of a gas foil bearing in this region is not possible. The first region encountered below the load capacity ray is a region of mixed lubrication. In this region the specific power loss is quite high and catastrophic failures occur quickly and without warning. For these reasons it is not recommended that foil bearings 
operate in a steady-state mode while in this region. The remaining two regions are the minimum power loss region and the lightly loaded region. Gas foil bearing operation in these two regions is characterized by low specific power loss and the ability to recover from overload and special event conditions. Operation below and to the right of the power loss minimum region is the recommended design range for gas foil bearings.

One impediment to more widespread use of foil bearings in high speed turbomachines is the general lack of understanding of foil bearing performance at off-design speeds and at relevant bearing cavity conditions. Conversely, there exists a plethora of information on gas foil bearing performance and generator losses operating in air at 1 atmosphere of system pressure (Refs. 8, 12, and 13). There exist in the literature several experimental and computational studies that quantify the effects of geometry on both gas foil bearing performance (Refs. 14 and 15) and generator windage. However, the extensibility of the proposed nondimensionalization schemes to include widely varying fluid properties remains to be verified. The data contained herein provides experimental evidence to this end. Correlations at high pressures are necessary to provide preliminary guidance for the next generation oil-free turbomachines. Future closed Brayton cycle turbomachines may operate at very high pressures to capitalize on several benefits such as increased working fluid heat capacity, reduced turbomachinery size, reduced system weight, and enhanced reliability. However a major drawback, or unknown, in these high-pressure systems is the power loss due to windage both in the gas foil bearings and in the rotorstator gap within the generator.

\section{Generator Windage}

Windage losses occur between any two surfaces moving in relation to each other. The significance of these losses depends on the rotor surface speed, rotor-stator clearance, surface roughness, and fluid properties, in particular the pressure. In high-speed turbomachinery, these losses can become increasingly significant, especially in the narrow rotor-stator gaps or locations where the flow is typically turbulent. There has been technical interest in windage losses in high speed generators since the days of the Apollo program at the National Aeronautics and Space Administration (Refs. 16 to 19). Windage loss at high speeds continues to be an interest in turbomachinery design (Refs. 20 and 21). As is the case with gas foil bearings, a typical experimental approach has been to conduct experiments while parametrically varying geometric parameters and nondimensionalizing results with respect to parameters such as Taylor number. However, very little data is available which addresses the fluid property effects directly.

Laminar Taylor-Couette flow is characterized by the independence of torque with respect to fluid pressure or density. However current experiments show a direct relationship between pressure and torque, which is indicative

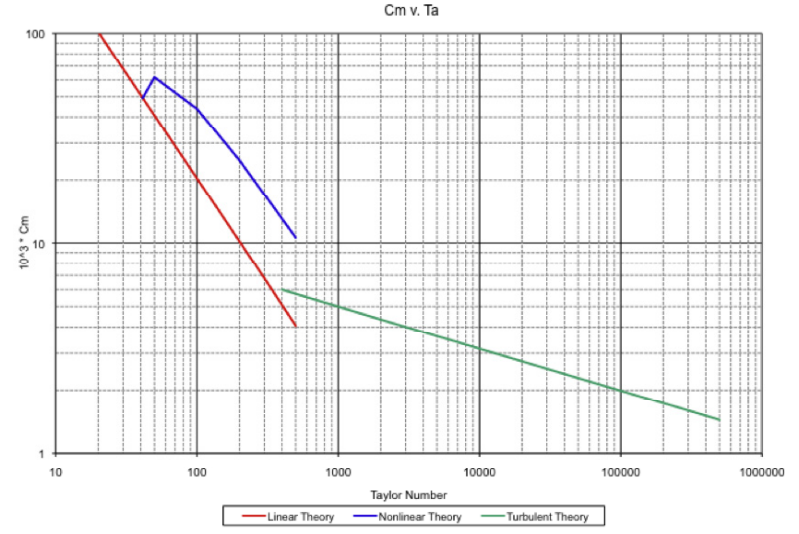

Figure 6.-The Taylor-Couette flow regions for concentric cylinders.

of turbulent flow. Most motors and generators rely on a small gap between the rotor and the stator to increase efficiency by decreasing the divergence of the magnetic field. However, decreasing the gap size increases the contribution of power loss due to windage. Understanding and being able to quantify how speed, pressure, gap size, and surface profile affect the windage losses for different working fluids enables the prediction of the efficiencies of motors and generators in highpressure systems. Experiments were conducted to directly measure the windage losses in a simulated rotor-stator gap operating in a high-pressure environment. Only the effects of circumferential flow were examined in these experiments. If a high axial throughflow is also present the results of this study may not be directly applicable.

The general system that is studied in the current experiment is the reaction torque between concentric cylinders, where the inner one is rotating, and the outer one is stationary. The Taylor-Couette flow theory (Ref. 22) is followed in this analysis. The general results of this theory are shown in Figure 6 . The theory predicts three regions of operation, one with completely laminar flow between the cylinders, one with Taylor vortices present, and one with turbulent flow between the cylinders. These regions can be described by relating the conditions of the experiment to two nondimensional values, moment coefficient $\left(C_{M}\right)$ and Taylor Number $\left(T_{a}\right)$.

$$
\begin{gathered}
T_{a}=\frac{U_{i} d}{v} \sqrt{\frac{d}{R i}} \\
C_{m}=\frac{M_{i}}{\frac{1}{2} \pi \rho U_{i}{ }^{2} R_{i}{ }^{2} h}
\end{gathered}
$$

The laminar region corresponds to a Taylor Number less than 41.3. In this region, the torque coefficient is related to the Taylor Number by the linear theory.

$$
C_{M}=A \sqrt{\frac{d}{R_{i}}} T_{a}^{-1}
$$


An important feature of the laminar region is that the reaction torque independent of fluid pressure or density. The effect of increased torque (power loss) with increasing pressure is due to the onset of turbulence and therefore is primarily a fluid inertia effect.

Once the Taylor Number exceeds 41.3, the flow becomes unstable, which leads to the development of Taylor vortices. These vortices rotate around an axis that follows a circular path around the rotor, and rotate in alternating opposite directions. The development of the vortices causes an initial jump in the torque coefficient, which then settles down and shows a relationship between the Taylor Number and torque coefficient similar to the linear theory, although at a high torque level.

Around a Taylor Number of 400, the flow becomes turbulent. The turbulent flow can be approximated by the formula:

$$
C_{M} \sim T_{a}^{-0.2}
$$

This proportionality can further be manipulated to show that turbulent torque does depend upon fluid density (or pressure).

$$
\text { dimensional_torque } \sim \mu^{0.2} \rho^{0.8} U^{2.1} R_{i}^{1.8} d^{-0.3} L
$$

The experiments that developed these theories used liquids and a single fixed radial gap to rotor diameter ratio. The current experiments are aimed at validating this theory for a variety of gasses at pressures up to 45 atmospheres. A number of gap to radius ratios has also been tested as well as representative rough stator configurations.

\section{The Test Rig}

The rig used in this study is the High-Pressure Rig. The rig is shown in Figure 7. The rig consists of a motor driven spindle and journal capable of speeds up to 42,000 revolutions per minute. Two test articles are used on this rig. The first article is used to test gas foil bearing performance. The second test article can directly measure windage torque. The drive motor and test article are completely encased in a pressure vessel that can be pressurized to 48 atmospheres with inert gas. Testing is limited to $38^{\circ} \mathrm{C}\left(100^{\circ} \mathrm{F}\right)$.

For the gas foil bearing test article radial loading is accomplished by placing balanced annular weights over the journal; as such the maximum load that can be tested in this rig is approximately $55 \mathrm{~N}, 61 \mathrm{kPa}(12 \mathrm{lbf}, 8.6 \mathrm{psi})$. This limit arises from both the available starting torque of the drive motor and the space constraints imposed by the pressure vessel. There is no ability to vary the applied radial load on this rig, which limits the steady state test data to lightly loaded conditions. A precision load cell is mounted close to the bearing center due to space limitations. This close coupling of the load cell also limits the range of reaction torque and power
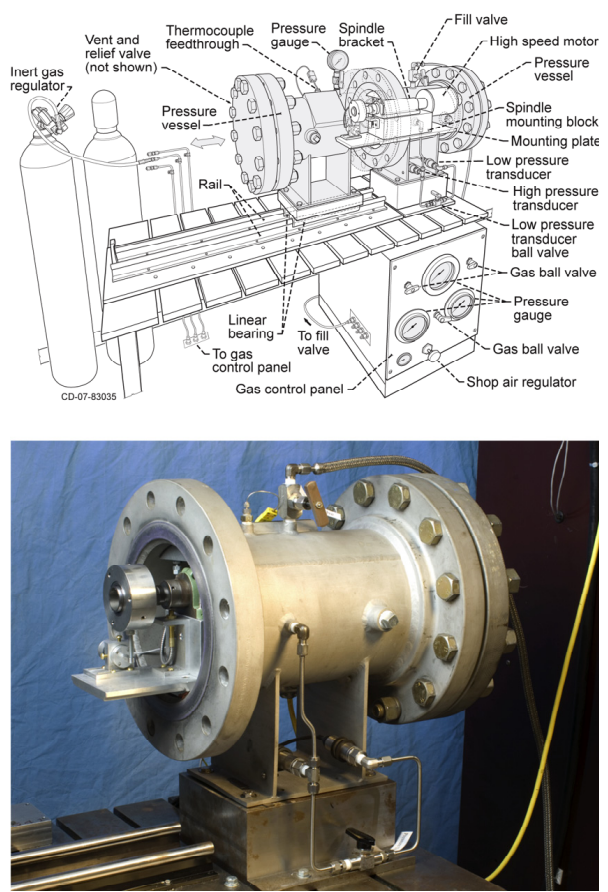

Figure 7.-The high pressure test rig.

loss that can be measured using this rig. The entire test rig is enclosed in a pressure vessel. This pressure vessel can be evacuated to 0.1 atmospheres and pressurized to 48 atmospheres. For the current test program helium, nitrogen, and carbon dioxide have been used as a foil bearing lubricant. Generation III foil journal bearings with uncoated Inconel top foils running against conditioned PS304 high temperature solid lubricant coated shafts were used in this study. The test procedure used on this rig includes a preliminary conditioning of the PS304 coated shaft, which includes running a series of start-stop cycles under radial load. High temperature start-stop cycles cannot be run on this rig, which therefore limits the load capacity coefficient to approximately $0.19 \mathrm{mN} /\left(\mathrm{mm}^{3}\right.$ $\mathrm{krpm})\left(0.7 \mathrm{lbf} /\left(\mathrm{in}^{3} \mathrm{krpm}^{3}\right)\right.$. The test procedure for this rig includes using one fixed, "deadweight" load, setting the chamber test gas and pressure, and accelerating to maximum speed as quickly as possible. Steady state data is then collected by reducing speed in set increments and recording reaction torque until the minimum power loss level is found. Figure 8 shows the relationship between bearing performance during a controlled acceleration from 0 to $42,000 \mathrm{rpm}$ and data obtained during a $5 \mathrm{~min}$ dwell time at a given speed to measure steady state data. This relationship allows for the determination of the power loss minimum point. Steady state testing is not continued into the mixed lubrication region due to the risk of thermal bearing failure in this region.

The test article, which was used to measure rotor-stator windage, is shown in Figure 9. The main modifications included a rotor attached to the motor spindle and a stator assembly. These are both mounted to the same plate. The rotor consists of a $35.3 \mathrm{~mm}$ (1.390 in.) diameter aluminum cylinder and is balanced with internal mass addition to be able 


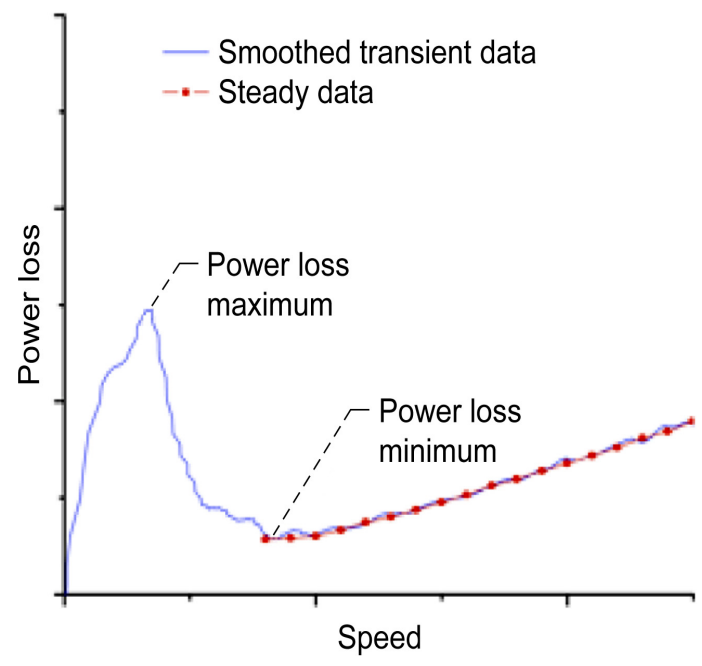

Figure 8.-Comparison of steady state gas foil bearing performance with controlled acceleration, transient performance.

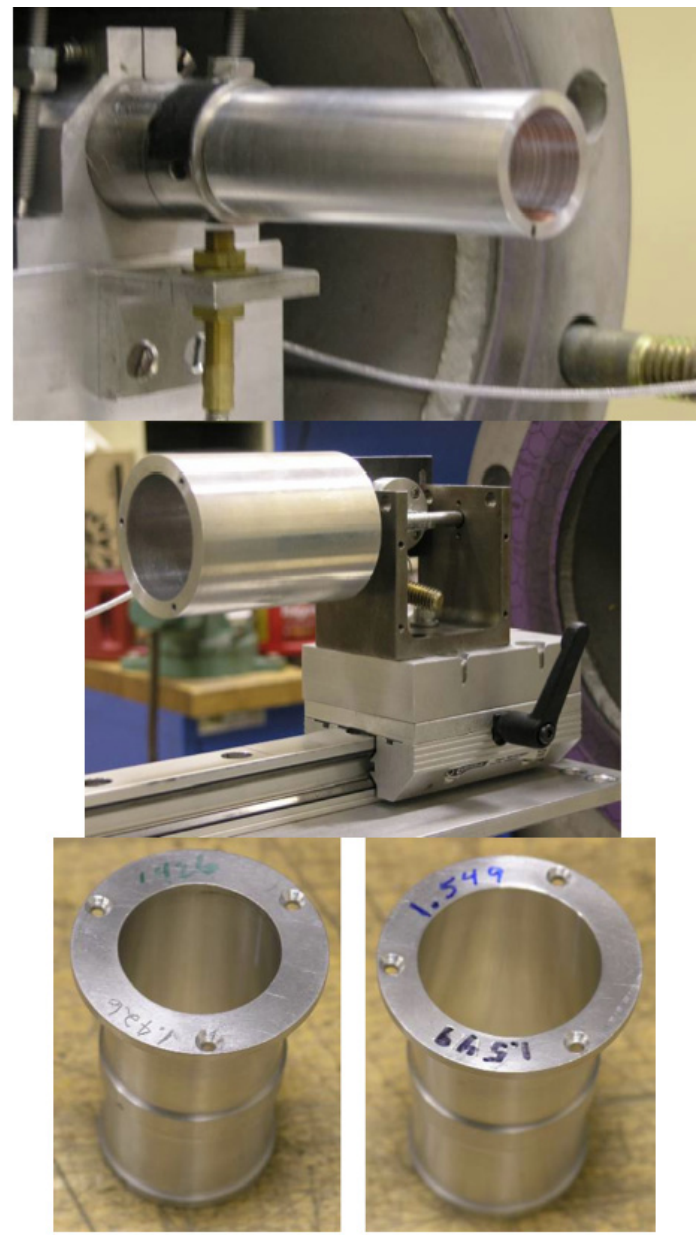

Figure 9.-Modifications made to the high pressure rig for rotor-stator gap windage experiments. (a) rotor mounted to motor shaft. (b) Stator assembly mounted to precision rail. (c) Various stator inserts. to rotate at speeds of up to 42,000 revolutions per minute without excessive vibrations or distortion. The stator assembly consists of a movable assembly, the stator is held in place by two high precision ball bearings, and a load cell. A lightweight, high strength monofilament is attached to the load cell and wraps around the shaft of the stator, constraining its rotational motion. In this arrangement, the stator is free in rotation allowing the load cell to measure the torque acting on the stator as a result of windage. The load cell is preloaded with a known torque to maintain a tension on the load cell.

The stator assembly is mounted on a sled, which can slide along a track mounted to the plate. This allows the stator to be easily moved back and forth, to adjust the overlap with the rotor, and to work on either the stator or the rotor without compromising the precision alignment.

The stator can be run with only the housing or various inserts can be added to change the gap size between the stator and the rotor. In the current experimental test program radial clearances of $0.0185,0.0795$, and 0.180 in. were tested. In addition, the inserts can be modified with strips of copper tape to model the surface profile that would be found on the inside of a typical motor or generator.

\section{Results}

Lightly loaded bearing performance data is presented in Figure 10. The data show power loss versus rotational speed for ambient pressures up to 48 atmospheres, $25{ }^{\circ} \mathrm{C}$. Results for helium, nitrogen, and carbon dioxide are presented for a constant load of $14 \mathrm{~N}$ (3.1 lbf). The data for carbon dioxide bearing performance is only shown for speeds below 21,000 revolutions per minute. At speeds greater than 21,000 revolutions per minute the rig vibrations rose dramatically, which caused unknown dynamic loads on the foil bearing. The vibrations were due to a rotordynamic problem with the journal mounting and were not caused by the test gas.

For helium the power loss trends at different pressures are nearly indistinguishable and follow the typical, mildly parabolic trend that is expected in hydrodynamic lubrication. For nitrogen and carbon dioxide the effect of pressure becomes quite pronounced. Although the trends converge at the minimum power loss point, there is a strong effect due to pressure as speed increases. The overall trend shows an increase in bearing power loss with increasing pressure.

Data has been obtained and analyzed for all clearances in air at 1 atmosphere, clearance of $4.5 \mathrm{~mm}$ (0.180 in.) in helium, nitrogen, and carbon dioxide up to 48 atmospheres, and for a "rough" clearance consisting of a nominal $2.0 \mathrm{~mm}(0.0795 \mathrm{in}$.) clearance with 75 micrometer $(0.003$ in.) simulated stator features. Figure 11 shows all experimental results plotted nondimensionally in terms of Taylor number and moment coefficient. Following the Taylor flow theory outlined in Equations (2) to (6), it appears as if all of the smooth wall data can be reduced to a single trend line provided the moment coefficient is modified by the square root of the 

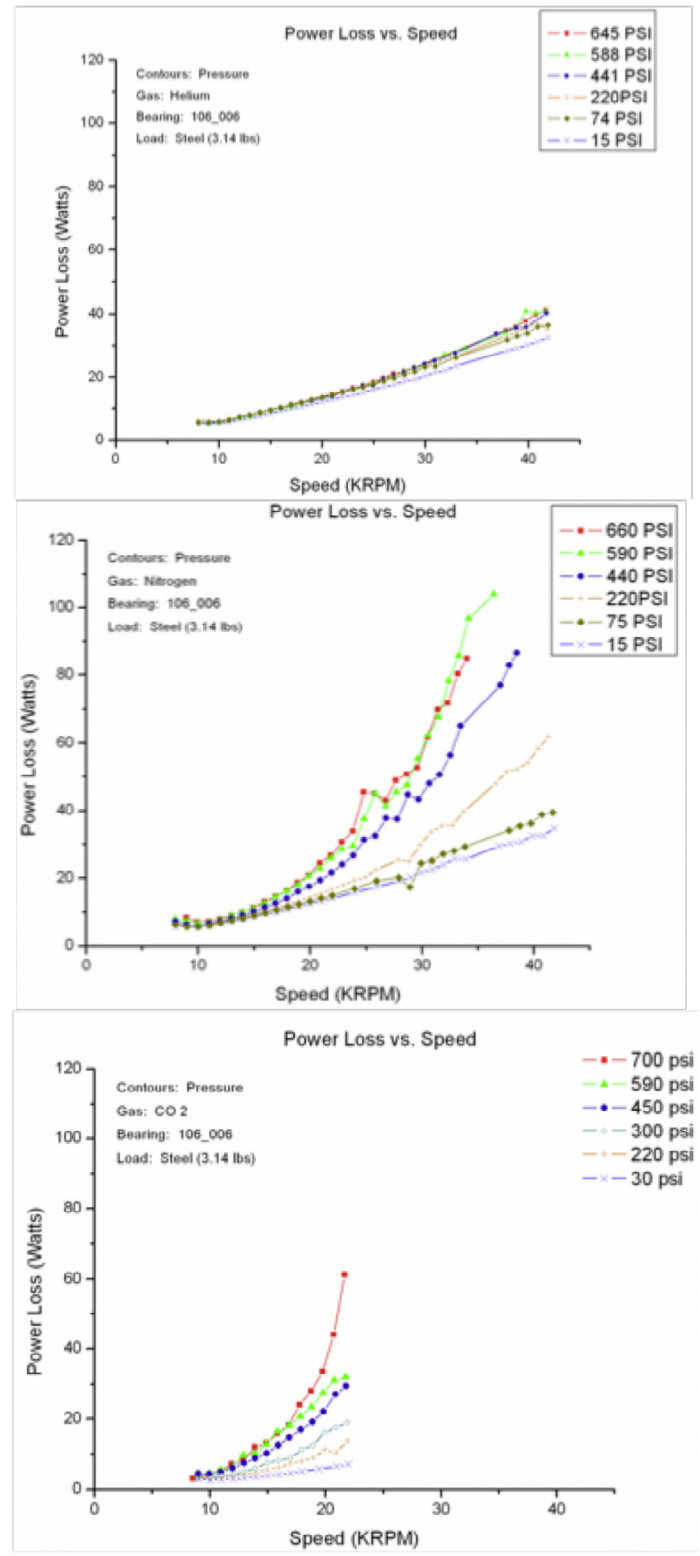

Figure 10.-_Lightly loaded gas foil bearing power loss for helium, nitrogen, and carbon dioxide.

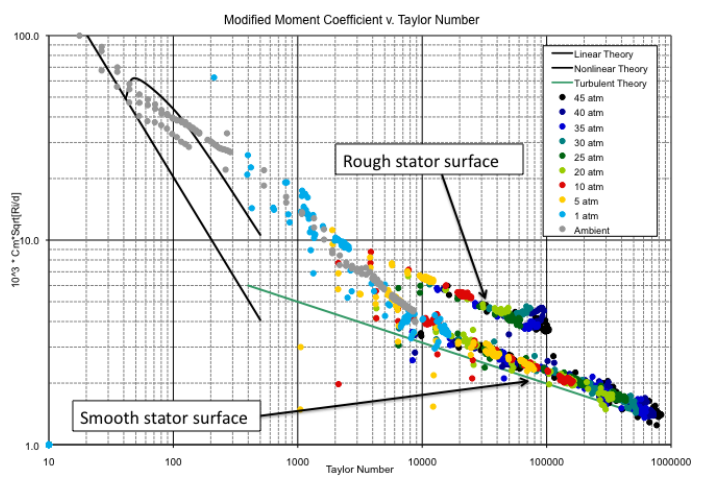

Figure 11.-Experimental rotor-stator windage results. clearance to radius ratio. A second trend line appears to capture the configuration with simulated roughness. The roughness data is currently limited in scope and no generalization can be made with regard to the thickness or pitch of the roughness. However, it would appear as though the general trend and data reduction method as found on the Moody charts for pipe flow would be applicable. The data presented in Figure 11 combined with Equations (2) to (6) can be used directly to estimate windage losses of future high pressure power cycles.

\section{Conclusions}

The experimental results presented herein provide quantitative characterization of the windage losses that can be expected in high pressure $\mathrm{CBC}$ and CSC power cycles for lightly loaded gas foil bearings and the rotor-stator clearance of the generator. The results for the gas foil bearing exhibit a strong influence of system pressure on the power loss when nitrogen or carbon dioxide are the lubricants. The gas foil bearing is not influenced by system pressure when helium is used as the lubricants. This indicates that there may be a fluid inertia effect, which is causing the higher power loss when using higher molecular weight lubricants. The generator windage can be nondimensionalized in terms of moment coefficient and Taylor number. Stator surface profiles that represent a rough profile have higher torque than the smooth walled stator. Future work is required to investigate the potential fluid inertia effect in gas foil bearings and to add fidelity to the Taylor-Couette correlation as applied to generator windage.

\section{References}

1. Mason, L., "A Power Conversion Concept for the Jupiter Icy Moons Orbiter," AIAA-2003-6007.

2. Halsey, D.G., Downing, R.S., Nguyen, D.C., Barrett, M.J., "Closed Brayton Cycle Engine Starter/Generator Cooling," AIAA-2005-3884.

3. Blok, H. and VanRussom, J., "The Foil Bearing-A New Departure in Hydrodynamic Lubrication," Lubrication Engineering, 1953.

4. Agrawal, G., "Foil Air/Gas Bearing Technology—An Overview," IGTI/ASME TurboExpo paper 97-GT-347.

5. DellaCorte, C., Valco, M.J., "Oil-Free Turbomachinery Technology for Regional Jet, Rotorcraft, and Supersonic Business Jet Propulsion Engines," Proceedings of the 2003 International Society of Airbreathing Engines Conference, Cleveland, Ohio, September 2003, ISABE Paper \#2003-1182.

6. Suriano, F.J., "Gas Foil Bearing Development Program," U.S. Airforce Report \#AFWAL-TR-81-2095.

7. Valco, M.J., DellaCorte, C., "Emerging Oil-Free Technology for Military Propulsion and Power 
Applications," Prodeedings of the ARMY Sciences Conferences, Ft. Lauderdale, FL, February 2003.

8. DellaCorte, C., Valco, M.J., "Load Capacity Estimation of Foil Air Journal Bearings for Oil-Free Turbomachinery Applications," NASA/TM-2000-209782.

9. DellaCorte, D., Lukaszewicz, V., Valco, M.J., Radil, K.C., Heshmat, H., "Performance and Durability of High Temperature Foil Air Bearings for Oil-Free Turbomachinery,” NASA/TM-2000-209187, March 2000.

10. DellaCorte, C., "Composition Optimization of $\mathrm{Cr}_{3} \mathrm{C}_{2}$ Based Solid Lubricant Coatings for Foil Gas Bearings at Temperatures to $650{ }^{\circ} \mathrm{C}$," NASA CR-179649, July 1987.

11. DellaCorte, C., Zaldana, A.R., Radil, K.C., "A Systems Approach to the Solid Lubrication of Foil Air Bearings for Oil-Free Turbomachinery," NASA/TM-2002211482.

12. DellaCorte, C., Radil, K., Bruckner, R.J., Howard, S.A., "A Preliminary Foil Gas Bearing Performance Map," NASA/TM-2006-214343, 2006.

13. Heshmat, H., Shapiro, W., Gray, S., "Development of Foil Journal Bearings for High Load Capacity and High Speed Whirl Stability," Transactions of the ASME Journal of Lubrication Technology, vol. 104, no. 2, pp. 149-156, April 1982.

14. Radil, K.C., Howard, S.A., Dykas, B., "The Role of Radial Clearance on the Performance of Foil Air Bearings," NASA/TM-2002-211705.
15. Dykas, B., Howard, S.A., "Journal Design Considerations for Turbomachine Shafts Supported on Foil Air Bearings," Tribology Transactions, vol. 47, no. 4, pp. 508-516, 2004.

16. Vrancik, J.E., "Prediction of Windage Power Loss in Alternators," NASA Technical Note TN D-4849, 1968.

17. Gorland, S.H., Kempke, E.E., Lumannick, S., "Experimental Windage Losses for Close Clearance Rotating Cylinders in the Turbulent Flow Regime," NASA Technical Memorandum TM X-52852, 1970.

18. Gorland, S.H., Kempke, E.E., "Experimental Windage Losses for a Lundell Generator Operating in Air in the Turbulent-Flow Region," NASA Technical Memorandum TM X-52905, 1970.

19. Gorland, S.H., Kempke, E.E., "Experimental Windage Studies for High-Speed Alternators," NASA Technical Memorandum TM X-67809, 1971.

20. Wild, P.M., Djilali, N., Vickers, G.W., "Experimental and Computational Assessment of Windage Losses in Rotaing Machinery," Transactions of the ASME, vol. 118, pp. 116-122, March 1996.

21. Saint Raymond, M., Kasarda, M.E.F., Allaire, P.E., "Windage Power Loss Modeling of a Smooth Rotor Supported by Homoplar Active Magnetic Bearings", Journal of Tribology, vol. 130, pp. 021101-1 to 021101-8, April 2008.

22. Schlichting, H., Boundary Layer Theory, McGraw-Hill, New York, 1987. 


\begin{tabular}{|c|c|c|}
\hline \multicolumn{2}{|c|}{ REPORT DOCUMENTATION PAGE } & $\begin{array}{l}\text { Form Approved } \\
\text { OMB No. 0704-0188 }\end{array}$ \\
\hline \multicolumn{3}{|c|}{$\begin{array}{l}\text { The public reporting burden for this collection of information is estimated to average } 1 \text { hour per response, including the time for reviewing instructions, searching existing data sources, gathering and maintaining the } \\
\text { data needed, and completing and reviewing the collection of information. Send comments regarding this burden estimate or any other aspect of this collection of information, including suggestions for reducing this } \\
\text { burden, to Department of Defense, Washington Headquarters Services, Directorate for Information Operations and Reports (070704-0188), } 1215 \text { Jefferson Davis Highway, Sulte } 1204 \text {, Arlington, VA } 222202-4302 \text {. } \\
\text { Respondents should be aware that notwithstanding any other provision of law, no person shall be subject to any penalty for failing to comply with a collection of information if it does not display a currently valid OMB } \\
\text { control number. } \\
\text { PLEASE DO NOT RETURN YOUR FORM TO THE ABOVE ADDRESS. }\end{array}$} \\
\hline $\begin{array}{l}\text { 1. REPORT DATE (DD-MM-YYYY) } \\
01-11-2009\end{array}$ & $\begin{array}{l}\text { 2. REPORT TYPE } \\
\text { Technical Memorandum }\end{array}$ & 3. DATES COVERED (From - To) \\
\hline \multirow{3}{*}{\multicolumn{2}{|c|}{$\begin{array}{l}\text { 4. TITLE AND SUBTITLE } \\
\text { Windage Power Loss in Gas Foil Bearings and the Rotor-Stator Clearance of High Speed } \\
\text { Generators Operating in High Pressure Environments }\end{array}$}} & 5a. CONTRACT NUMBER \\
\hline & & 5b. GRANT NUMBER \\
\hline & & 5c. PROGRAM ELEMENT NUMBER \\
\hline \multirow{3}{*}{\multicolumn{2}{|c|}{$\begin{array}{l}\text { 6. AUTHOR(S) } \\
\text { Bruckner, Robert, J. }\end{array}$}} & 5d. PROJECT NUMBER \\
\hline & & 5e. TASK NUMBER \\
\hline & & $\begin{array}{l}\text { 5f. WORK UNIT NUMBER } \\
\text { WBS 877868.02.07.03.01.01.14 }\end{array}$ \\
\hline \multicolumn{2}{|c|}{$\begin{array}{l}\text { 7. PERFORMING ORGANIZATION NAME(S) AND ADDRESS(ES) } \\
\text { National Aeronautics and Space Administration } \\
\text { John H. Glenn Research Center at Lewis Field } \\
\text { Cleveland, Ohio 44135-3191 }\end{array}$} & $\begin{array}{l}\text { 8. PERFORMING ORGANIZATION } \\
\text { REPORT NUMBER } \\
\text { E- } 17088\end{array}$ \\
\hline \multirow{2}{*}{\multicolumn{2}{|c|}{$\begin{array}{l}\text { 9. SPONSORING/MONITORING AGENCY NAME(S) AND ADDRESS(ES) } \\
\text { National Aeronautics and Space Administration } \\
\text { Washington, DC 20546-0001 }\end{array}$}} & $\begin{array}{l}\text { 10. SPONSORING/MONITOR'S } \\
\text { ACRONYM(S) } \\
\text { NASA }\end{array}$ \\
\hline & & $\begin{array}{l}\text { 11. SPONSORING/MONITORING } \\
\text { REPORT NUMBER } \\
\text { NASA/TM-2009-215826 }\end{array}$ \\
\hline \multicolumn{3}{|c|}{$\begin{array}{l}\text { 12. DISTRIBUTION/AVAILABILITY STATEMENT } \\
\text { Unclassified-Unlimited } \\
\text { Subject Categories: } 07 \text { and } 20 \\
\text { Available electronically at http://gltrs.grc.nasa.gov } \\
\text { This publication is available from the NASA Center for AeroSpace Information, 443-757-5802 }\end{array}$} \\
\hline
\end{tabular}

13. SUPPLEMENTARY NOTES

\section{ABSTRACT}

Closed Brayton Cycle (CBC) and Closed Supercritical Cycle (CSC) engines are prime candidates to convert heat from a reactor into electric power for robotic space exploration and habitation. These engine concepts incorporate a permanent magnet starter/generator mounted on the engine shaft along with the requisite turbomachinery. Successful completion of the long-duration missions currently anticipated for these engines will require designs that adequately address all losses within the machine. The preliminary thermal management concept for these engine types is to use the cycle working fluid to provide the required cooling. In addition to providing cooling, the working fluid will also serve as the bearing lubricant. Additional requirements, due to the unique application of these microturbines, are zero contamination of the working fluid and entirely maintenance-free operation for many years. Losses in the gas foil bearings and within the rotor-stator gap of the generator become increasingly important as both rotational speed and mean operating pressure are increased. This paper presents the results of an experimental study, which obtained direct torque measurements on gas foil bearings and generator rotor-stator gaps. Test conditions for these measurements included rotational speeds up to 42,000 revolutions per minute, pressures up to 45 atmospheres, and test gases of nitrogen, helium, and carbon dioxide. These conditions provided a maximum test Taylor number of nearly one million. The results show an exponential rise in power loss as mean operating density is increased for both the gas foil bearing and generator windage. These typical "secondary" losses can become larger than the total system output power if conventional design paradigms are followed. A nondimensional analysis is presented to extend the experimental results into the CSC range for the generator windage.

\section{SUBJECT TERMS}

Foil bearings; Closed cycles; Brayton cycles; High pressure; Turbomachinery

\begin{tabular}{|c|c|c|c|c|c|}
\hline \multicolumn{3}{|c|}{ 16. SECURITY CLASSIFICATION OF: } & $\begin{array}{l}\text { 17. LIMITATION OF } \\
\text { ABSTRACT } \\
\text { UU }\end{array}$ & $\begin{array}{l}\text { 18. NUMBER } \\
\text { OF } \\
\text { PAGES } \\
14\end{array}$ & $\begin{array}{l}\text { 19a. NAME OF RESPONSIBLE PERSON } \\
\text { STI Help Desk (email:help@sti.nasa.gov) } \\
\text { 19b. TELEPHONE NUMBER (include area code) } \\
\text { 443-757-5802 }\end{array}$ \\
\hline
\end{tabular}



